\title{
List of Abbreviations
}

Works by Paul de Man

AI Aesthetic Ideology, ed. Andrzej Warminski (Minneapolis: University of Minnesota Press, 1996)

AR Allegories of Reading: Figural Language in Rousseau, Nietzsche, Rilke, and Proust (New Haven: Yale University Press, 1979)

BI Blindness and Insight: Essays in the Rhetoric of Contemporary Criticism, Second Edition, Revised (Minneapolis: University of Minnesota Press, 1983)

RCC Romanticism and Contemporary Criticism: The Gauss Seminar and Other Papers, ed. E. S. Burt, Kevin Newmark, and Andrzej Warminski (Baltimore: Johns Hopkins University Press, 1993)

$R R \quad$ The Rhetoric of Romanticism (New York: Columbia University Press, 1984)

RT The Resistance to Theory (Minneapolis: University of Minnesota Press, 1986) 